\title{
Aquamarine from Thach Khoan Mining Area in Phu Tho Province, Vietnam
}

\author{
Ly Thuy Duong ${ }^{1, *}$, Le Thi Thu Huong ${ }^{2}$ \\ ${ }^{1}$ Faculty of Geology, VNU University of Science, 334 Nguyen Trai, Hanoi, Vietnam \\ ${ }^{2}$ University of Graz, Austria \\ Received 20 January 2017 \\ Revised 16 March 2017; Accepted 28 June 2017
}

\begin{abstract}
Aquamarine is a kind of gemstone having attractive color, valuable and being a potential material in gemological industry. In Vietnam, Thach Khoan area has become a noticeable location to explore aquamarine. However, the researches of aquamarine are still limited. Therefore, this study was conducted to determine the characteristics of aquamarine. Eight aquamarine samples from granitic pegmatites in Thach Khoan commune, Thanh Son District, Phu Tho Province were investigated by classical gemological methods, Electron Probe Micro-analysis (EMPA) and Laser Ablation - Inductively Coupled Plasma - Mass Spectrometry (LA-ICP-MS) methods, Raman and Fourier transform infrared (FTIR) spectroscopy. Results showed that aquamarine presents a low concentration of alkali and high amount of iron. Raman and IR spectroscopy indicate the vibrations of specific bonds including $\mathrm{Si}-\mathrm{O}, \mathrm{Al}-\mathrm{O}, \mathrm{Be}-\mathrm{O}$, the presence of $\mathrm{CO}_{2}$ and type $\mathrm{I}_{2} \mathrm{O}$ in structural channels. By dint of that, we are going to study the potential treatment methods of aquamarine in Vietnam in the following study to enhance its quality as well as value in the global market.
\end{abstract}

Keywords: Aquamarine, Electron Probe Micro-analysis (EMPA), Electron Probe Micro-analysis (EMPA), Raman spectroscopy.

\section{Introduction}

Aquamarine is a variety of beryl $\left(\mathrm{Be}_{3} \mathrm{Al}_{2} \mathrm{Si}_{6} \mathrm{O}_{18}\right)$ with the color of light blue to dark blue, green-blue and crystallized in hexagonal system. As we can see from figure 1, the structure of beryl in the projection perpendicular to the c-axis is shown on the left

\footnotetext{
* Corresponding author. Tel.: 84-1687461077

Email: lythuyduong.k56@gmail.com

https://doi.org/10.25073/2588-1094/vnuees.4090
}

side while the right side illustrates the position of $\mathrm{H}_{2} \mathrm{O}$ and $\mathrm{CO}_{2}$, a cation in the structural channel. The structure is composed of sixmembered rings of $[\mathrm{SiO} 4]^{4-}$ - tetrahedrons. These rings stack one above the other along the c-axis forming large structural channel site that is big enough to host many molecules such as $\mathrm{H}_{2} \mathrm{O}, \mathrm{CO}_{2}, \mathrm{CH}_{4}, \mathrm{NO}^{3-}$ and $\mathrm{CO}_{3}{ }^{2-}$. In the channel site, there are two types of water existences. Type I of water occur alone and its symmetry axis is perpendicular to the c-axis; type II is water molecules, which are associated 
with nearby alkalis, and the water molecule symmetric axis is parallel to c-axis.

In Vietnam, the first discovery of aquamarine was in Xuan Le commune, Thuong Xuan district, Thanh Hoa province in 1985. This area is known as a place having the best quality aquamarine. Aquamarine found good hexagonal formed crystal and are generally light blue to blue with moderate saturation. Some specimens can be found in deep sky blue. The detail description about Thuong Xuan aquamarine was published in 2011 [1]. Furthermore, aquamarine was also discovered in other areas such as Ha Giang, Nghe An, Khanh Hoa provinces but aquamarine in Thach Khoan commune, Thanh Son district, Phu Tho province is more remarkable.

Thach Khoan commune lies about $80 \mathrm{~km}$ northwest of Hanoi city (figure 2) [2]. This area is affected by faults with the main trend of northwest-southeast of Red River shear zone and Hoang Lien Son zone [3, 4]. These faults play an important role in structural formation of this area. The aquamarine is hosted by pegmatite distributed mostly within Thach Khoan formation. The pegmatite bodies typically are veins, lenses or pockets, elongate towards northwest-southeast direction and comfort with country rock. Big bodies are several meters in length and $10-50 \mathrm{~m}$ in thickness, and small ones are centimeters in thickness and extend a few meters in length. The pegmatite bodies contain the dominant minerals including $15 \%$ quartz, $35 \% \mathrm{~K}$ feldspar, $30 \%$ plagioclase, $10 \%$ muscovite, 0 $3 \%$ biotite and a very small proportion of others such as aquamarine, topaz, tourmaline, fluorite, pyrite and so on [5]. In addition, the fingerprint inclusions are relatively popular [5].

Aquamarine crystals from Thach Khoan typically show a prismatic habit and measure 3$4 \mathrm{~cm}$ in diameter, although some crystals attain about 10-30 cm in length [5]. Some gem- and carving-quality aquamarine has been recovered, although the fact that most of the crystals contain numerous inclusions. Because a lack of reports about aquamarine from Thach Khoan (Phu Tho) and a few of gemstones are faceted, this article is as an instruction of the characteristics of aquamarine from the study area and compare with another one from Thuong Xuan (Thanh Hoa). The study contributes to the improvement of aquamarine quality and the control of its drawbacks.
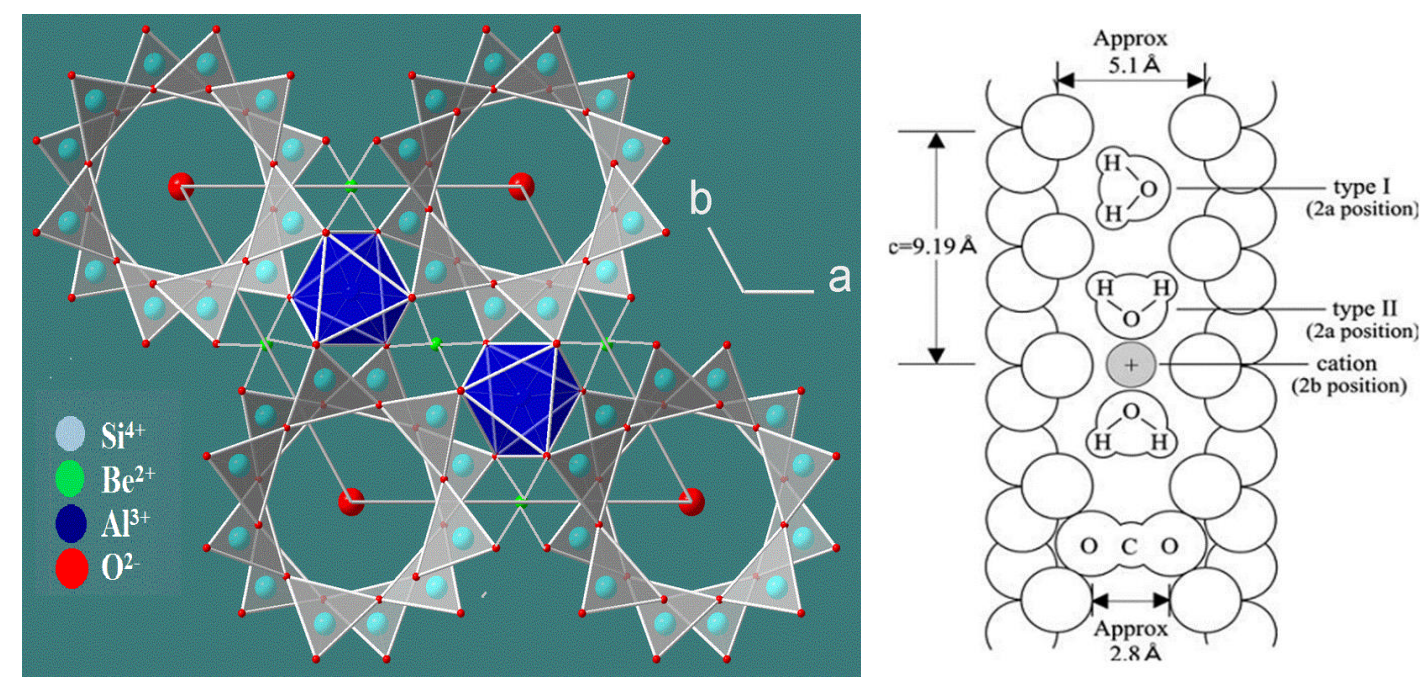

Figure 1. The crystal structure of beryl [2] and the position of $\mathrm{H}_{2} \mathrm{O}$ and $\mathrm{CO}_{2}$, a cation in the structural channel [3]. 


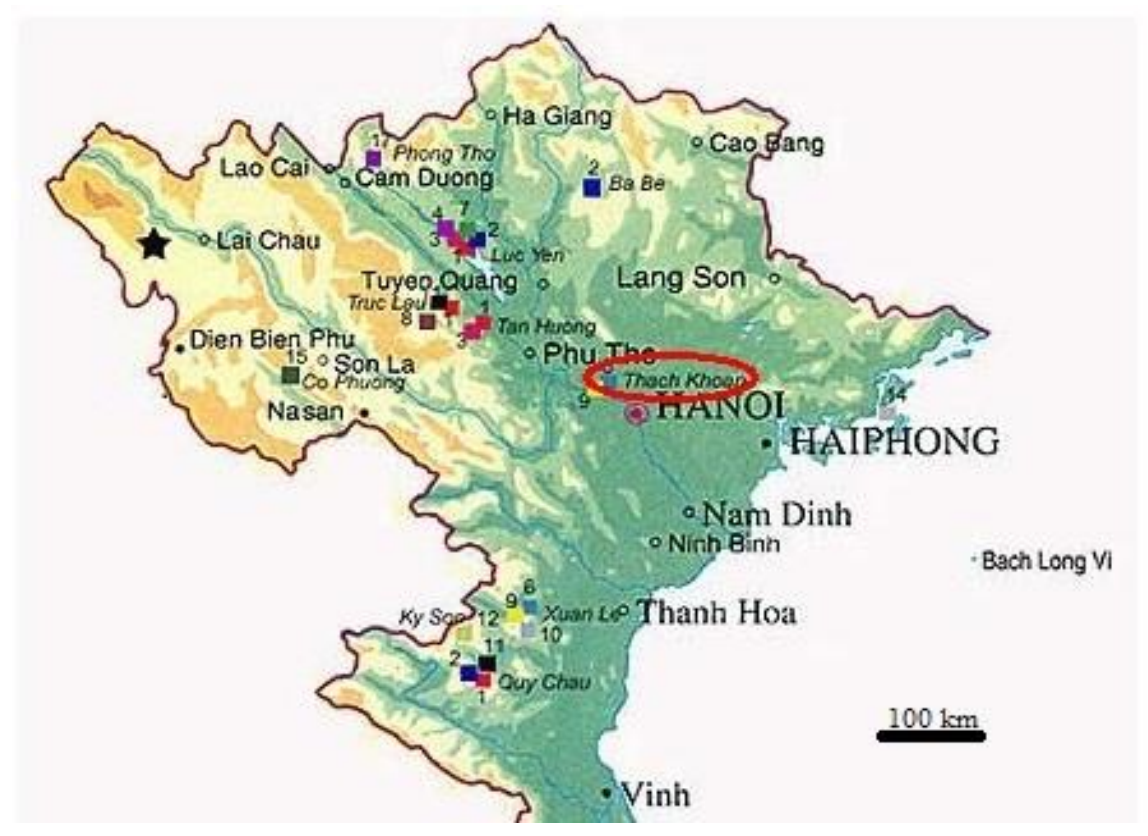

Figure 2. Location of Thach Khoan deposite [2].

\section{Materials and methods}

Figure 3 indicates the typical color of aquamarine from Thach Khoan mining area. In this study, we examined eight samples for studying the characteristics of aquamarine.

Chemical analyses were performed on the three polished specimens by Electron probe micro-analysis (EMPA) and Laser Ablation Inductively Coupled Plasma - Mass Spectrometry (LA-ICP-MS) at the Institute of Geosciences, Johannes Gutenberg University Mainz, Germany. EMPA was carried out by using a Cameca SX 100 electron microprobe with the wave dispersion mode (WDS), imaged by back-scattered electrons (BSE). The following analytical conditions were applied: $15 \mathrm{kV}$ accelerating voltage, $20 \mathrm{nA}$ beam current, and 5-10 $\mu \mathrm{m}$ beam diameter. The chemical elements selected for analysis include $\mathrm{Be}, \mathrm{Al}, \mathrm{Si}, \mathrm{Fe}, \mathrm{Mg}, \mathrm{Mn}, \mathrm{Ca}, \mathrm{Sc}, \mathrm{Na}, \mathrm{K}, \mathrm{Li}$ and Sc. Counting times of 20 to 40 seconds were used. The detection limits of measured elements range from 0.02 to $0.1 \mathrm{wt} \%$, and statistical errors from 0.02 to $0.08 \mathrm{wt} . \%$, depending on the elemental concentration. The electronmicroprobe analytical data was reduced using the PAP routine. LA-ICP-MS was used to determine the trace elements composition in aquamarine samples. Analyses were conducted with a New Wave UP213 Nd: YAG FeststoffLaser with an output wavelength of $213 \mathrm{~nm}$ coupled to an Agilent 7500ce quadrupole ICP-MS.

Fourier transform infrared (FTIR) spectrometer was utilized to determine the infrared absorption spectra of specific bonding. The infrared absorption spectra were recorded in the range of 500 to $4500 \mathrm{~cm}^{-1}$ (wave numbers) using Nicolet 6700 spectrometer equipped with a transmittance attachment. This instrument has standard resolution of $0.09 \mathrm{~cm}^{-1}$ and requires Omnic software to collect data and draw spectra chart. Measurements were performed at room temperature. Background adjustments were made for spectral artifacts caused by atmospheric $\mathrm{H}_{2} \mathrm{O}$ and $\mathrm{CO}_{2}$. All samples analyzed by this technique are polished rough crystals. 

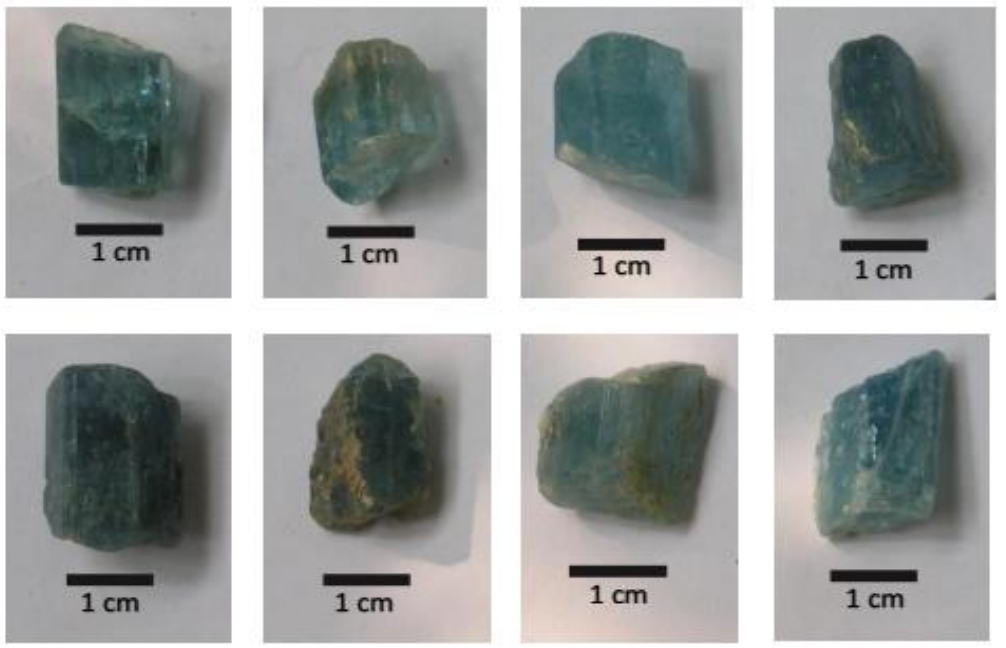

Figure 3. Typical color of rough aquamarine samples from Thach Khoan, Phu Tho province. Photos were taken by student.

Raman spectroscopy was used to detector. Spectra were excited by $\mathrm{Ar}^{+}$ion laser investigate the occurrences of specific bonds, $\mathrm{H}_{2} \mathrm{O}$ and $\mathrm{CO}_{2}$ molecules in the beryl structural channels, as these can show differences between aquamarines from different sources, and to identify inclusions in selected samples. The spectra were collected by Renishaw Ir Via Raman microscope. The system is equipped with an Olympus BX41 optical microscope and a Si-based CCD (charge-coupled device) emission with $514 \mathrm{~nm}$ as a green laser and a slit width of $100 \mu \mathrm{m}$. Due to these parameters and the optical path length of the spectrometer a resolution of $0.8 \mathrm{~cm}^{-1}$ resulted.

\section{Results and discussion}

Visual appearance and gemological properties
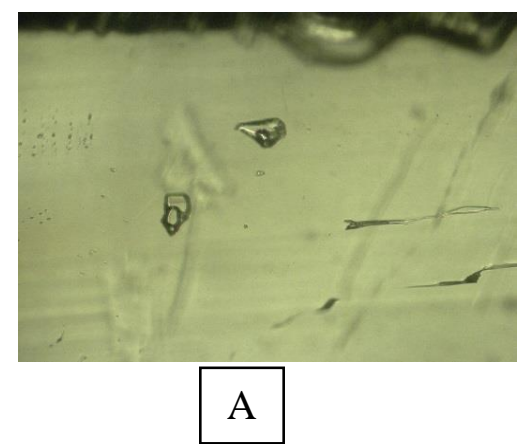

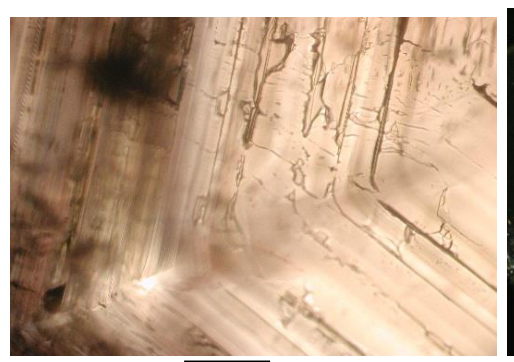

$\mathrm{B}$

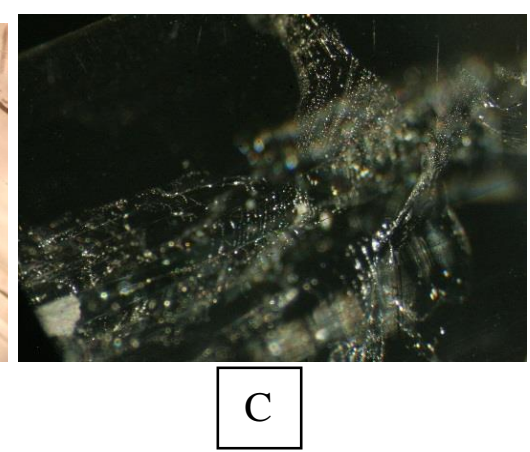

Figure 4. Inclusions in aquamarine from Thach Khoan commune, Phu Tho province containing A. 2-phase inclusions, B. Parallel growth lines, C. The fingerprint inclusion. Photos observed by student and photographed by Le Thi Thu Huong. 


\begin{tabular}{|c|c|c|c|}
\hline $\begin{array}{l}\text { Chemical } \\
\text { composition }\end{array}$ & Sample 1 & Sample 2 & Sample 3 \\
\hline \multicolumn{4}{|c|}{ Oxides (wt.\%) } \\
\hline $\mathrm{BeO}$ & 13.401 & 13.523 & 12.591 \\
\hline $\mathrm{Al}_{2} \mathrm{O}_{3}$ & 18.131 & 17.796 & 18.546 \\
\hline $\mathrm{SiO}_{2}$ & 65.420 & 65.870 & 66.410 \\
\hline $\mathrm{Fe}_{2} \mathrm{O}_{3}$ & 1.495 & 1.418 & 1.367 \\
\hline $\mathrm{MgO}$ & 0.046 & 0.058 & 0.000 \\
\hline $\mathrm{MnO}$ & 0.012 & 0,009 & 0.011 \\
\hline $\mathrm{CaO}$ & 0.046 & 0.030 & 0.027 \\
\hline $\mathrm{Sc}_{2} \mathrm{O}_{3}$ & 0.005 & 0.005 & 0.005 \\
\hline $\mathrm{Na}_{2} \mathrm{O}$ & 0.025 & 0.048 & 0.037 \\
\hline $\mathrm{K}_{2} \mathrm{O}$ & 0.007 & 0.003 & 0.006 \\
\hline $\mathrm{Li}_{2} \mathrm{O}$ & 0.009 & 0.001 & 0.002 \\
\hline $\mathrm{Cs}_{2} \mathrm{O}$ & 0.193 & 0.126 & 0.132 \\
\hline Total & 98.79 & 98.878 & 99.134 \\
\hline $\mathrm{H}_{2} \mathrm{O}$ & 1.21 & 1.122 & 0.866 \\
\hline \multicolumn{4}{|c|}{$\begin{array}{l}\text { Trace elements } \\
\text { (ppm) }\end{array}$} \\
\hline $\mathrm{B}$ & 1.87 & 2.82 & 2.33 \\
\hline $\mathrm{P}$ & 49.5 & 17.62 & 40.20 \\
\hline $\mathrm{Ti}$ & 6.18 & 3.07 & 2.24 \\
\hline $\mathrm{V}$ & 0.525 & 0.477 & 0.198 \\
\hline $\mathrm{Cr}$ & 2.06 & 1.52 & 2.53 \\
\hline Co & 0.247 & 0.134 & 0.082 \\
\hline $\mathrm{Ni}$ & 1.9 & 5.0 & 0.8 \\
\hline $\mathrm{Ga}$ & 71.36 & 71.23 & 70 \\
\hline $\mathrm{Ge}$ & 0.85 & 0.63 & 1.06 \\
\hline $\mathrm{Rb}$ & 58.09 & 54.87 & 55.72 \\
\hline $\mathrm{Sr}$ & 0.047 & 0.125 & 0.51 \\
\hline Y & 0.042 & 0.018 & 0.046 \\
\hline $\mathrm{Zn}$ & 0.13 & 0.123 & 0.06 \\
\hline $\mathrm{Nb}$ & 0.027 & 0.0227 & 0.037 \\
\hline Mo & 0.082 & 0.103 & 0.223 \\
\hline $\mathrm{Ba}$ & 0.178 & 0.152 & 0.78 \\
\hline $\mathrm{La}$ & 0.024 & 0.033 & 0.019 \\
\hline $\mathrm{Ta}$ & 0.022 & 0.011 & 0.030 \\
\hline
\end{tabular}


The polished stones ranged from light to medium blue, and were transparent to opaque. Gemological testing gave the following properties: $\mathrm{RI}=1.57-1.58, \mathrm{SG}=2.649-2.677$, and inert to both long- and shortwave UV radiation. The samples were fairly heavy and no pleochroism under dichroscope. Besides, microscopic examination revealed inclusions containing two-phase (fluid and gas) inclusions, growth lines and figureprint inclusions (figure 4). In addition, gas inclusions were detected by Raman spectroscopy at a band $1242 \mathrm{~cm}^{-1}$ related to the vibration of $\mathrm{CO}_{2}$ molecules in the beryl structural channels [1].

Chemical composition: EMPA and LAICP-MS measurements are showed in table 1. As can be seen from the table, the contents of major elements ( $\mathrm{Si}, \mathrm{Be}, \mathrm{Al})$ occupy a great proportion in samples with 65.420 to 66.410 wt. $\%$ of $\mathrm{SiO}_{2}, 17.796$ to 18.546 wt.\% of $\mathrm{Al}_{2} \mathrm{O}_{3}$ and 12.591 to 13.523 wt.\% of $\mathrm{BeO}$. The contents of major oxides approach to the ideal contend of beryl (67.07 wt.\% of $\mathrm{SiO}_{2}, 18.97$ wt. $\%$ of $\mathrm{Al}_{2} \mathrm{O}_{3}, 13.96 \mathrm{wt} \%$ of $\mathrm{BeO}$ ) [8]. These data is almost similar to other aquamarines collected from various locations such as aquamarine from Bazil, Nigeria [9] or Thuong Xuan aquamarine [1]. EMPA measurements (table 1) also showed a distinct amount of the chromophore $\mathrm{Fe}$ (1.367-1.495 wt.\% of $\mathrm{Fe}_{2} \mathrm{O}_{3}$ ). Other possible coloring elements $(\mathrm{Ti}, \mathrm{V}, \mathrm{Cr}$, $\mathrm{Mn})$ were present at very low trace levels $(<<0.1$ wt.\%), as were the alkalis. Among alkalis, the contents of Cs is relatively high (up to 0.193 wt. $\%$ of $\mathrm{Cs}_{2} \mathrm{O}$ ). Relying on these data, our samples can be considered as low-alkalibearing beryl.

\section{FTIR spectroscopy:}

$3500 \mathrm{~cm}^{-1}$ to $3800 \mathrm{~cm}^{-1}$ region and $1500 \mathrm{~cm}$ ${ }^{1}$ to $1700 \mathrm{~cm}^{-1}$ region: The stretching vibrations of water occur in the regions; thus, a detailed study was performed to identify and quantify the water molecules. Most researchers agree that water type $\mathrm{I}$ has $\mathrm{H}-\mathrm{H}$ vector paralleling to c-axis correlating to chemical composition as alkalis' contents are very low and shows main absorptions at $3700 \mathrm{~cm}^{-1}$ [10] and $1625 \mathrm{~cm}^{-1}$ [11]. Therefore, they don't affect the orientation of water molecule. It is reason why the peak of water type II that has $\mathrm{H}-\mathrm{H}$ vector being normal with c axis don't observed in this spectra (figure 5). In agreement with the chemical composition, the IR spectrum prove that this sample is a typical of low-alkali-bearing beryl.

$2200 \mathrm{~cm}^{-1}$ to $2400 \mathrm{~cm}^{-1}$ region and $400 \mathrm{~cm}^{-1}$ to $1300 \mathrm{~cm}^{-1}$ region: In the first region, $\mathrm{CO}_{2}$ is represented by two complementary peaks at $2341 \mathrm{~cm}^{-1}$ and $2359 \mathrm{~cm}^{-1}$ [12]. In the second region, the infrared spectrum absorptions characteristic of the $\mathrm{Be}-\mathrm{O}, \mathrm{Si}-\mathrm{O}, \mathrm{Si}-\mathrm{O}-\mathrm{Al}$, and Al-O stretching are displayed [12-14]. In the range between $600 \mathrm{~cm}^{-1}$ and $400 \mathrm{~cm}^{-1}$, the bands correspond to $\mathrm{Li}-\mathrm{O}$ vibrations [15]. However, the band at $527 \mathrm{~cm}^{-1}$ belongs to vibrations of Al-O [12]. The bands appearing at about 809 $\mathrm{cm}^{-1}, 743 \mathrm{~cm}^{-1}$, and $682 \mathrm{~cm}^{-1}$ are applied to the $\mathrm{Be}-\mathrm{O}$ bond [14]. Other bands in the range between $800 \mathrm{~cm}^{-1}$ and $1300 \mathrm{~cm}^{-1}$ have been identified to the internal Si-O vibrations [14] (figure 5).

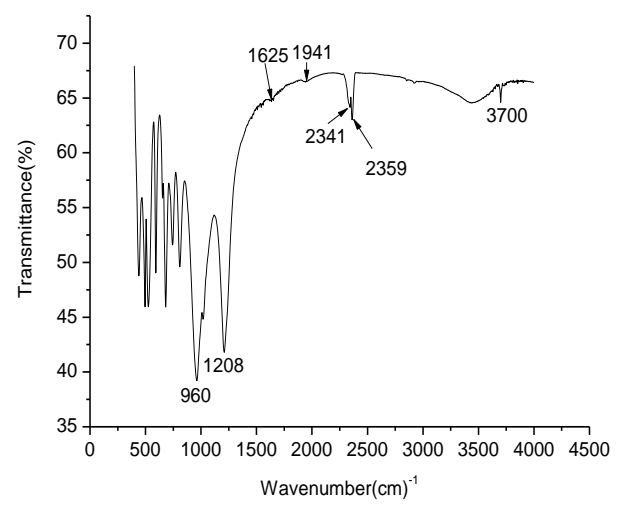

Figure 5. The IR spectrum of aquamarine from Thach Khoan commune, Phu Tho province in the range of $400-4500 \mathrm{~cm}^{-1}$. 


\section{Raman spectroscopy:}

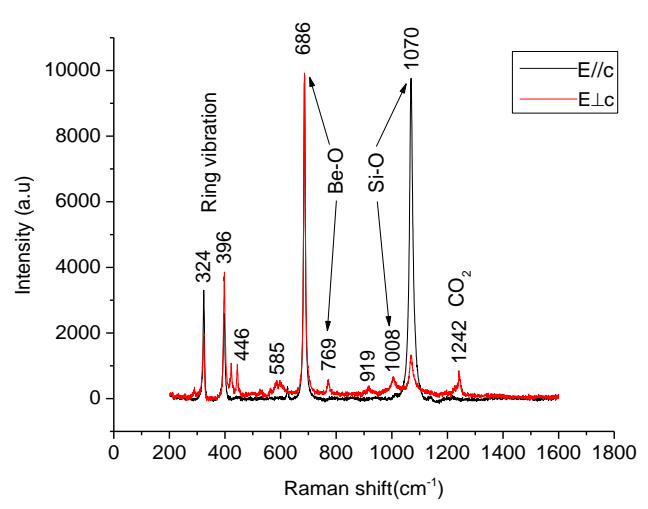

Figure 6. The comparison of Raman spectra of aquamarine from Thach Khoan communce, Phu Tho province between $\mathrm{E} / / \mathrm{c}$ and $\mathrm{E} \perp \mathrm{c}$.

By comparison Raman spectra between two electronic vector orientations $(E / / c$ and $E \perp c)$, some bands are relatively similar at the Raman shift of 323-324 cm$-1,396 \mathrm{~cm}^{-1}, 686 \mathrm{~cm}^{-1}, 1070$ $\mathrm{cm}^{-1}$. Meanwhile, others only appear in one of two figures. The bands at $323 \mathrm{~cm}^{-1}, 396 \mathrm{~cm}^{-1}$ have been assigned to ring vibrations [13], and the bands around $1008 \mathrm{~cm}^{-1}$ and around 1070 $\mathrm{cm}^{-1}$ have been assigned to Si-O bond [16] Moreover, the bands appearing at $769 \mathrm{~cm}^{-1}$ and $686 \mathrm{~cm}^{-1}$ were ascribed to the Be-O cluster [17]. The band at $525 \mathrm{~cm}^{-1}$ correlates to Al-O stretching [12]. Another band can be seen in higher ranges, the appearance of $\mathrm{CO}_{2}$ was seen at the band of $1242 \mathrm{~cm}^{-1}$ [1] (figure 5). These bands are seen only when electronic vector was perpendicular to the c-axis, and they absolutely disappear when electronic vector was parallel to the c-axis. This phenomenon is caused by the vibration of $\mathrm{CO}_{2}$ molecules existence in the channels of crystal structure. The disappearance of these bands when electronic vector was parallel to the $\mathrm{c}$-axis proves that the $\mathrm{CO}_{2}$ molecule is oriented normally to the c-axis.

The comparison between aquamarines from Thach Khoan and Thuong Xuan:
The specimens from two different sources have some similar features including the feature about inclusions, the feature about chemical ingredient (characterized by high iron contents, low alkaline concentration) and also some features about spectroscopy showing the occurrences of $\mathrm{CO}_{2}$, type $\mathrm{I}$ of water in two samples. By contrast, varied points still exist inside aquamarine from two different locations. To specify, aquamarine from Thuong Xuan included the hematite inclusion [1] while it was not detected in another one from Thach Khoan. On the other hand, the specimen from Thuong Xuan was contaminated by iron. By virtue of the reason above, it is possible to consider that aquamarine from Thach Khoan is clearer.

\section{Conclusion}

Aquamarine from Thach Khoan shows typical gemological properties and may be readily distinguished using a combination of gemological, chemical, and spectroscopic features. Careful observation of pleochroism, fluorescence, and internal features can provide useful indicators (eg, $\mathrm{SG}=2.469-2.677$, $\mathrm{RI}=1.57-1.58$, inclusions) for gemologists with basic equipments. More-sophisticated techniques such as Raman and FTIR spectroscopy, as well as chemical analysis, can provide clear proof of the identification.

With EMPA and LA-ICP-MS analysis, the main components approach to the ideal beryl's contents; besides, trace and minor elements were found in aquamarine are low. Notwithstanding, the concentration of $\mathrm{Fe}$ and Cs is comparatively high compared with others in various types of beryl. Because of low alkali contents, aquamarines from Thach Khoan are classified as alkali-poor beryl.

Spectroscopic features show well crystallized structure of aquamarine as well as the attendance of $\mathrm{CO}_{2}$ and type $\mathrm{I}-\mathrm{H}_{2} \mathrm{O}$ in structural channel. 
Aquamarines from Thach Khoan are comparable with others from Thuong Xuan. They have some similar characteristics. However, we need to investigate in more samples to assemble information exactly.

\section{References}

[1] L. T.T. Huong, W. Hofmeister, T. Häger, N. N. Khoi., N. T. Nhung, W. Atichat and V. PisuthaArnond, Aquamarine from Thuong Xuan district, Thanh Hoa province, Gem \& Gemology, 47 (2011) 42.

[2] P. V. Long, G. Giuliani, V. Garnier and D. Ohnenstetter, Gemstones in Vietnam: A review, Australian Gemmologist, 22 (2004) 162.

[3] http://idm.gov.vn/nguon_luc/Xuat_ban/Anpham/ Tracuu_PVDC/A3.htm\#Ailaoshan_SongHong

[4] Le Thac Xinh, Metallogeny of the Hoang Lien Son subduction zone, GEOSEA V Proceedings, 2 (1986) 525.

[5] Tran Anh Ngoan, Characteristics of endogenic mineralizations in the Thạch Khoán - Ba Vì area (in Vietnamese), Journal of Geology, (2002).

[6] J. T. David, Mineralogical and geochemical study of the true blue aquamarine showing, shark property, souhtern Yukon territory, Thesis of Master of Science, The University of Bristish Columbia, 2005.

[7] J. Fukida and K. Shinoda, Coordination of water molecules with $\mathrm{Na}$ cations in a beryl channel as determined by polarized IR spectroscopy, Physics and Chemistry of minerals, 35 (2008) 347.
[8] http://webmineral.com/data/Beryl.shtml\#.VW4sR $3 \mathrm{M} 2 \mathrm{XBY}$

[9] I. Adamo, A. Pavese,L. Prosperi, V. Diella, D. Ajo, G.D. Gatta and. C.P. Smith, Aquamarine, Maxixe-type beryl, and hydrothermal synthetic blue beryl: Analysis and identification, Gem and Gemology, 44 (2008) 214.

[10] I. M. Rudolf and S. Z. Smirnov, The nature of channel constituents in hydrothermal synthetic emerald, Journal of Gemmology, 29 (2004) 215.

[11] D.L. Wood and K. Nassau, Infrared spectra of foreign molecules in beryl, The Journal of Chemical Physics, 47 (1967) 2220.

[12] B. Charoy, P. D. Donato, O. Barres, C. PintoCoelho, Channel occupancy in an alkali-poor beryl from Serra Branca (Goias, Brazil): Spectroscopic characterization, American Mineralogist, 81 (1996) 395.

[13] C. Aurisicchio, O. Grubessi, P. Zecchini, Infrared spectroscopy and crystal chemistry of the beryl group, The Canadian Mineralogist, 32 (1994) 55.

[14] A. M. Hofmeister, T.C. Hoering and D. Virgo, Vibrational spectroscopy of beryllium aluminosilicates: Heat-capacity calculations from band assignments, Physics and Chemistry of Minerals, 14 (1987) 205.

[15] F. P. Stewart, K. Refson, R. I. Bewley and G. Dent, Assignment of the vibrational spectra of lithium hydroxide monohydrate, $\mathrm{LiOH}-\mathrm{H}_{2} \mathrm{O}$, The journal of chemical physics, 134 (2011).

[16] D. M. Adams and I.R. Gardner, Single-crystal vibrational spectra of beryl and dioptase, Journal of the Chemical Society - Dalton Transactions, 1974 (1974) 1502.

[17] Hawthorne F.C. and P. Černý, The alkali-metal positions in Cs-Li beryl, Canadian Mineralogist, 15 (1977) 414. 


\title{
Aquamarin ở mỏ khai thác Thạch Khoán thuộc tỉnh Phú Thọ, Việt Nam
}

\author{
Lý Thùy Dương ${ }^{1}$, Lê Thị Thu Hương ${ }^{2}$ \\ ${ }^{1}$ Khoa Địa chất, Trường Đại học Khoa học Tự nhiên, ĐHQGHN, 334 Nguyễn Trãi, Hà Nội, Việt Nam \\ ${ }^{2}$ Đại học Graz, Áo
}

Tóm tắt: Aquamarin là một loại đá quý có màu sắc hấp dẫn, có giá trị kinh tế và là một loại vật liệu giàu tiềm năng trong ngành công nghiệp đá quý. Ở Việt Nam, Thạch Khoán trở thành một khu vực khai thác đang được quan tâm. Tuy nhiên, các nghiên cứu về aquamarine vẫn còn hạn chế. Do đó, nghiên cứu này được thực hiện để xác định những đặc điểm của aquamarin. Tám mẫu aquamarin được lây từ các khối đá pegmatit granit ở xã Thạch Khoán, huyện Thanh Sơn, tỉnh Phú Thọ đã được nghiên cứu bằng các phương pháp ngọc học cơ bản, phương pháp phân tích hiển vi điện tử (EMPA), phương pháp khối phổ kế plasma đầu dò laser (LA-ICP-MS), phương pháp phương pháp quang phổ Raman và quang phổ hồng ngoại chuyển đổi Fourier (FTIR spectroscopy). Kết quả cho thấy những mẫu này chứa hàm lượng kiềm thấp và hàm lượng sắt cao. Phổ Raman và phổ hồng ngoại xác định các dao động của những liên kết đặc trưng như $\mathrm{Si}-\mathrm{O}, \mathrm{Al}-\mathrm{O}, \mathrm{Be}-\mathrm{O}$ và sự hiện diện của $\mathrm{CO}_{2}$ và $\mathrm{H}_{2} \mathrm{O}$ loại $\mathrm{I}$ trong kênh cấu trúc. Từ đó, chúng tôi sẽ tiếp tục nghiên cứu về các phương pháp xử lý tiềm năng cho aquamarin ở Việt Nam trong thời gian tới để nâng cấp chất lượng cũng như giá trị của loại đá quý này trên thị trường thế giới.

Tư khóa: Aquamarin, phân tích hiển vi điện tử (EMPA), quang phổ hồng ngoại chuyển đổi Fourier (FTIR spectroscopy), quang phổ Raman. 